\title{
PERUBAHAN SOSIAL BUDAYA DAN KETERKAITANNYA TERHADAP PEMBELAJARAN IPS
}

\author{
Monalisa Rahman \\ Email: 2010128220010@mhs.ulm.ac.id \\ Program Studi Pendidikan IPS Fakultas Keguruan dan Ilmu Pendidikan \\ Universitas Lambung Mangkurat \\ Banjarmasin
}

\begin{abstract}
Abstrak
Kehidupan bermasyarakat merupakan suatu hal yang bersifat dinamis. Setiap kehidupan akan selalu mengalami perubahan, baik secara lambat maupun cepat. Perubahan itu dapat terjadi pada pola perilaku individu masyarakat, organisasi, nilai, norma sampai pendidikan. Dalam konteks kehidupan bermasyarakat, perubahan terbagi menjadi dua macam, yakni perubahan sosial dan perubahan kebudayaan. Namun, di dalam kehidupan bermasyarakat sangat sulit untuk ditemukan inti perbedaan di antara keduanya itu, sebab sangat sulit untuk menetapkan inti pemisah antara masyarakat dengan kebudayaan. Masyarakat dan kebudayaan merupakan dua elemen yang berbeda tapi tidak bisa dipisahkan secara empiris, sebab keduanya itu mempunyai kaitan fungsional bagi kelangsungan hidup masyarakat. Namun, dalam kehidupan bermasyarakat banyak orang yang menyamakan makna dari keduanya, bahkan ada orang yang menyebutnya perubahan sosial budaya. Meskipun demikin antara perubahan sosial dan perubahan budaya memiliki komponen yang sama, yakni keduanya saling berkaitan dengan penerimaan cara-cara baru atau suatu renovasi dari cara-cara masyarakat dalam memenuhi kebutuhan hidupnya.
\end{abstract}

\section{PENDAHULUAN}

Kehidupan bermasyarakat merupakan suatu hal yang bersifat dinamis, setiap kehidupan akan selalu mengalami perubahan, perubahan dapat terjadi pada pola perilaku individu masyarakat ataupun organisasi, perubahan dalam norma sosial, interaksi dan juga pendidikan. Adapun perubahan yang berpengaruh terbatas dan ada juga yang luas serta ada perubahan yang lambat atapun perubahan yang lambat. Kehidupan bermasyarakat tidak akan terhenti pada satu titik tertentu di suatu masa. Perubahan-perubahan itu bisa berupa nilai sosial, norma sosial, pola perilaku masyarakat atau lembaga yang lainnya. William F. Oqbun, beropini bahwa ruang lingkup perubahan sosial budaya mencakup aspek-aspek kebudayaan, baik dari segi material ataupun yang inmaterial (Syamsidar, 2015: 99-100).

Kehidupan bermasyarakat itu dinamis, jadi perubahan yang terjadi di masyarakat merupakan suatu kejadian atau fenomena yang wajar atau normal pengaruhnya bahkan bisa menular dan merambah ke belahan dunia laindengan cepat sebab didukung oleh 
kemajuan teknologi infomasi dan komunikasi yang canggih. Selain itu penemuanpenemuan baru dibidang teknologi juga sangat mempengaruhi perubahan sosial budaya yang nantinya akan berdampak pada pendidikan (Syamsidar, 2015: 100).

Suatu perubahan sosial budaya yang terjadi akan berpengaruh pada tatanan kehidupan bermasyarakat yang lainnya. Seperti perubahan gaya fashion yang akan menghasilkan akibat pada perekonomian masyarakat, sebab suatu hal yang sedang trend akan cenderung diikuti dan di imitasi oleh masyarakat yang menyukai hal-hal tersebut. Sama halnya dengan dampak dari perubahan sosial budaya akan berakibat pada pendidikan atau suatu proses pembelajaran.

\section{METODE PENELITIAN}

Metode yang digunakan adalah metode kepustakaan atau studi literatur yaitu dengan menelaah dan memahami isi buku-buku, dokumen, atau sumber ilmiah lainnya yang relevan dan mendukung untuk mendeskripsikan konsep perubahan sosial budaya dan kaitannya terhadap pembelajaran IPS.

\section{KONSEP PERUBAHAN SOSIAL-BUDAYA}

Dalam konteks kehidupan bermasyarakat, ada dua macam perubahan, yakni perubahan sosial dan perubahan kebudayaan. Namun, di dalam kehidupan bermasyarakat sangat sulit untuk ditemukan inti perbedaan antara perubahan sosial dan perubahan budaya, sebab sulit untuk menetapkan inti pemisah antara masyarakat dengan kebudayaan. Masyarakat dan kebudayaan merupakan dua dasar yang berbeda tapi tidak bisa dipisahkan secara empiris, sebab keduanya itu mempunyai kaitan fungsional bagi kelangsungan hidup masyarakat. Hal demikian dikarenakan tidak ada kebudayaan yang tidak lahir dari suatu masyarakat, artinya sebenarnya pendukung kebudayaan ialah masyarakat bukan individu atau perorangan. Sehingga, meskipun secara teori pemisahan antara definisi-definisi itu dapat disimpulkan, tetapi pada kenyataannya memang inti pemisah di antara keduanya itu sulit untuk ditetapkan (Ningrum, 2015: 21).

Namun hal tersebut, dalam kehidupan bermasyarakat banyak orang yang menyamakan makna dari keduanya, bahkan ada orang yang menyebutnya perubahan sosial budaya. Meskipun demikin antara perubahan sosial dan perubahan budaya 
memiliki komponen yang sama, yakni keduanya saling berkaitan dengan penerimaan cara-cara baru atau suatu renovasi dari cara-cara masyarakat dalam memenuhi kebutuhan hidupnya. Perubahan sosial budaya yang terjadi di masyarakat seiring dengan sifat manusia yang dinamis dan selalu mengalami perubahan dari waktu ke waktu. Perubahan tersebut ada yang berlangsung lambat dan ada juga yang cepat, ada perubahan kecil dan perubahan besar atau juga dapat berupa perubahan yang disengaja dan tidak disengaja. Perubahan sosial budaya itu bisa berupa norma-norma, nilai-nilai, pola-pola sikap, sistem organisasi sosial, bentuk dan jenis benda budaya, dan lain sebagainya (Ningrum, 2015: 21-22).

Adapun definisi perubahan sosial budaya menurut Selo Soemardjan (1983: 49), perubahan sosial budaya merupakan segala perubahan yang terjadi pada lembagalembaga kemasyarakatan di dalam suatu tatanan bermasyarakat yang mempegaruhi sistem sosialnya, termasuk nilai-nilai dan pola perilaku di antara kelompok dalam masyarakat. Sedangkan menurut Gillin dan Gillin, menyatakan bahwa perubahan sosial budaya adalah sebagai suatu keragaman dari cara hidup yang telah diterima, baik sebab perubahan keadaan geografis, kebudayaan material komposisi penduduk, ideologi, ataupun karena adanya penyebaran budaya atau penemuan baru dalam masyarakat (Ningrum, 2015: 22).

Perubahan sosial budaya yang terjadi di masyarakat bisa dibedakan menjadi beebrapa bentuk yaitu sebagai berikut:

a. Perubahan yang terjadi secara lambat dan perubahan yang terjadi secara cepat Perubahan yang terjadi secara lambat itu disebut dengan evolusi, perubahan ini memerlukan waktu yang lama, yang mana terdapat suatu runtutan perubahan kecil yang saling berkesinambungan. Pada proses evolusi, perubahan-perubahan terjadi dengan sendirinya, tanpa adanya suatu rencana ataupun keinginan tertentu. Sedangkan perubahan yang terjadi secara cepat itu disebut dengan revolusi, yang mana perubahan yang terjadi cepat yang mengenai dasar atau sendi pokok kehidupan bermasyarakat, yakni lembaga-lembaga kemasyarakatan. Contohnya revolusi industri yang mengakibatkan berubahnya dasar atau sendi kehidupan masyarakat, seperti mendorong lahirnya imperialisme modern, liberalisme ekonomi, munculnya ideologi sosialisme, individualisme, korelasi buruh dan majikan, perebutan daerah jajahan dan lain sebagainya (Ningrum, 2015: 23). 
b. Perubahan yang menyebabkan pengaruh yang kecil dan perubahan yang menyebabkan perngaruh yang besar

Perubahan yang pengaruhnya kecil merupakan perubahan yang terjadi terhadap unsur-unsur struktur sosial yang tidak mempengaruhi langsung atau memberikan pengaruh yang berarti bagi masyarakat, contohnya perubahan fashion, perubahan gaya rambut Sebaliknya perubahan yang pengaruhnya besar merupakan peruahan yang terjadi terhadap unsur-unsur struktur sosial yang mempengaruhi langsung atau yang memberikan pengaruh yang berarti bagi masyarakat, contohnya ledakan penduduk atau industrialisasi bagi konsep kehidupan bermasyarakat (Syamsidar, 2015: 102).

c. Perubahan yang dikehendaki/ direncanakan dan perubahan yang tidak dikehendaki/ tidak direncanakan

Perubahan yang dikehendaki atau direncanakan adalah perubahan yang telah diduga, direncanakan terlebih dahulu oleh pihak yang ingin melakukan perubahan di masyarakat. Pihak itu disebut dengan agen of change, yakni orang atau sekelompok orang yang memperoleh kepercayaan masyarakat untuk merubah suatu sistem sosial. Contohnya pelaksanaan pembangunan atau perubahan tatanan pemerintahan, seperti perubahan pemerintahan orde baru menjadi tata pemerintahan orde reformasi. Sebaliknya perubahan yang tidak dikehendaki atau tidak direncanakan ialah perubahan yang terjadi tidak terduga di luar jangkauan pengawasan masyarakat dan bisa mengakibatkan timbulnya hal yang tidak diharapkan. Contohnya timbulnya berbagai kejadian atau peristiwa kerusuhan menjelang masa peralihan tatanan orde lama ke orde baru dan peralihan tatanan orde baru ke masa reformasi (Syamsidar, 2015: 102-103).

Adapun arah atau tujuan perubahan sosial budaya, modernisasi dan pembangunan yang akan dituju oleh masyarakat bangsa manapun ialah meningkatkan kesejahteraan dan kemakmuran yang diinginkan. Berikut arah perubahan sosial budaya, diantaranya sebagai berikut:

a. Konsumerisme, ialah pandangan hidup bahwa lebih baik jika membeli atau menggunakan produk barang atau jasa daripada membuatnya sendiri.

b. Konsumtivisme, merupakan sikap yang suka mengonsumsi barang atau jasa yang sebenarnya bukan kebutuhannya. 
c. Hedonisme, yaitu cara hidup bermewah atau berfoya untuk mengejar prestise atau gengsi tertentu.

d. Kesenjangan sosial ekonomi, merupakan ketidakadilan dalamproses pembangunan, seperti sebab memprioritaskan daerah atau golongan tertentu.

e. Munculnya berbagai perilaku menyimpang, seperti kenakalan remaja, narkoba, prostitusi, dan lain sebagainya yang dikarenakan oleh adanya keinginan untuk menyesuaikan dengan taraf hidup, tapi tidak didukung oleh keterampilan dan kemampuan yang memadai (Syamsidar, 2015: 103).

Adapun secara umum faktor-faktor yang menyebabkan terjadinya perubahan sosial budaya terbagi menjadi beberapa faktor yakni faktor intern dan faktor ekstern. Berikut penjelasan mengenai faktor yang menyebabkan terjadinya perubahan sosial budaya:

a. Faktor intern

Faktor yang bersumber dari dalam masyarakat itu sendiri yakni:

1. Bertambah dan berkurangnya penduduk

Bertambahnya penduduk bisa mengakibatkan terjadinya perubahan tatanan masyarakat, khususnya yang menyangkut lembaga-lembaga kemasyarakatan, seperti lembaga sistem hak milik atas tanah, gadai tanah, sewa tanah, bagi hasil dan lainnya. Selain itu juga dengan berkumpulya penduduk kemungkinan akibat dari urbanisasi atau transmigrasi yang menyebabkan perubahan dalam segi pembagian kerja, stratifikasi sosial dan juga dapat mempengaruhi lembaga-lembaga kemasyarakatan (Ningrum, 2015: 24-25).

2. Penemuan-penemuan baru

Inovasi, proses ini mencakup suatu penemuan baru, unsur kebudayaan baru itu disebarkan ke bagian lain di masyarakat, lalu diterima, kemudian dipelajari dan digunakan dalam artian discovery dan invention. Adapun discovery merupakan penemuan suatu unsur kebudayaan yang baru, baik berupa suatu alat, ide, gagasan, metode, teknik baru yang diciptakan oleh individu ataupun kelompok dalam masyarakat yang bersangkutan. Sedangkan invention adalah jika masyarakat sudah mengakui, meuji, menerima dan menerapkan penemuan baru itu dalam masyarakat bersangkutan. Ada beberapa 
faktor yang mendorong munculnya penemuan-penemuan baru dalam masyarakat, ialah diantaranya adanya kesadaran masyarakat akan kekurangan kebudayaan, mengetahui kualitas para ahli dalam suatu kebudayaan, pendorong bagi aktivitas penciptaan dalam masyarakat, adanya pengaruh aspek budaya asing yang lebih bermanfaat bagi kehidupan masyarakat dan adanya organisasi atau lembaga sosial yang mendoronh ke arah penemuan baru itu (Ningrum, 2015: 25).

\section{Konflik dalam masyarakat}

4. Terjadinya pemberontakan atau revolusi di dalam masyarakat

b. Faktor ekstern

Faktor yang bersumber dari luar masyarakat itu sendiri yakni:

1. Sebab yang berasal dari lingkungan alam, seperti gempa bumi, banjir, tanah longsor, gunung meletus.

2. Peperangan

3. Pengaruh dari kebudayaan masyarakat lain

Kebudayaan masyarakat lain yang masuk dan mempengaruhi serta menyebabkan terjadinya perubahan dalam suatu masyarakat, umumnya tingkat kebudayaanny alebih tinggi tingkatannya meskipun nantinya menyatu atau terpadu dengan menciptakan atau menghasilkan kebudayaan baru. Perpaduan kebudayaan itu disebut dengan akulturasi (Ningrum, 2000: 26-27).

Adapun faktor-faktor yang mempengaruhi proses perubahan sosial budaya, yakni sebagai berikut:

a. Faktor yang mendorong jalannya proses perubahan, meliputi:

1. Adanya proses komunikasi atau kontak dengan kebudayaan asing.

2. Sistem pendidikan yang maju pesat.

3. Adanya perilaku menghargai hasil cipta karya orang laindan mempunyai kemauan untuk maju.

4. Sikap toleransi pada tindakan yang memyimpang (deviation), yang bukan termasuk tindak pidana (delik).

5. Sistem pelapisan masyarakat yang transparan (open stratification).

6. Penduduk yang heterogen. 
7. Sikap ketidakpuasan masyarakat pada bidang kehidupan tertentudan adanya hambatan untuk memperbaiki.

8. Terjadinya disrganisasi dalam masyarakat.

9. Adanya perilaku mudah menerima hal-hal baru/

10. Berorietasi ke masa depan.

11. Berpandangan bahwa manusia harus cenderung untuk memperbaiki hidupmya.

b. Faktor yang menghalangi terjadinya perubahan, mencakup:

1. Berkembangnya IPTEK yang lambat

2. Kurangnya komunikasi atau kontak dengan masyarakat lain.

3. Sikap masyarakat yang masih tradisional, atau enggan menerima inovasi/ pembaruan.

4. Adanya sikap rasa takut akan terjadinya kegoyahan dalam integrasi kebudayaan.

5. Menduga-duga tidak baik terhadap hal yang baru.

6. Hambatan yang bersifat ideologi.

7. Kebiasaaan yang menolak inovasi/ pembaruan.

8. Berpandangan bahwa hidup pada dasarnya buruk dan tidak perlu diperbaiki (Ningrum, 2015: 27-28).

Berikut tadi penjelasan mengenai apa itu perubahan sosial budaya, perbedaan antara perubahan sosial dan perubahan kebudayaan. Lalu ada bentuk perubahan sosial budaya yakni perubahan sosial yang terjadi secara lambat dan cepat, perubahan yang dikehendaki dan tidak dikehendaki dan perubahan yang menyebabkan pengaruh besar dan kecil. Selain itu juga membahas mengenai faktor-faktor terjadinya perubahan sosial budaya, baik faktor pendukung maupun faktor penghambat jalannya perubahan sosial budaya.

\section{KETERKAITAN DAN PENGARUH PERUBAHAN SOSIAL-BUDAYA TERHADAP PEMBELAJARAN IPS}

Antropologi mengutarakan bagaimana kemampuan individu atau masyarakat dalam menciptakan hasil kebudayaan dengan perkembangannya dari kondisi yang sederhana kepada kondisi yang semakin maju, ialah sumber dan materi yang harus dipelajari dalam pengajaran IPS. Bagaimana daya penyesuaian diri individu ataupun 
masyarakat diberbagai ruang geografis terhadap kondisi lingkungan setempat yang menghasilkan tingkat kebudayaan yang berbeda-beda adalah materi yang berarti untuk memupuk definisi para siswa kepada kemampuan budaya masyarakat yang berbedabeda (Hati, 2018: 13).

Keragaman budaya juga dapat memupuk saling pengertian antar kelompok yang menjadi asas kerjasama di antara kelompok-kelompok yang berkaitan. Iklim dan kemampuan ini harus dipupuk, ditanam dan disajikan pada pembelajaran IPS, sehingga kita sebagai calon guru bisa membukakan pikiran mengenai pengertian peserta didik seluas-luasnya hingga mereka tidak akan meremehkan dan merendahkan tradisi atau kebiasaan yang berlaku di masyarakat lain (Hati, 2018: 13).

\section{SIMPULAN}

Perubahan sosial budaya menurut Selo Soemardjan (1983: 49), perubahan sosial budaya merupakan segala perubahan yang terjadi pada lembaga-lembaga kemasyarakatan di dalam suatu tatanan bermasyarakat yang mempegaruhi sistem sosialnya, termasuk nilai-nilai dan pola perilaku di antara kelompok dalam masyarakat. Sedangkan menurut Gillin dan Gillin, menyatakan bahwa perubahan sosial budaya adalah sebagai suatu keragaman dari cara hidup yang telah diterima, baik sebab perubahan keadaan geografis, kebudayaan material komposisi penduduk, ideologi, ataupun karena adanya penyebaran budaya atau penemuan baru dalam masyarakat (Ningrum, 2015: 22).

Kemudian ada bentuk-bentuk perubahan sosial budaya secara umum yaitu perubahan sosial yang terjadi secara lambat dan cepat, perubahan yang dikehendaki/ direncanakan dan tidak dikehendaki/ direncanakan dan perubahan yang menyebabkan pengaruh besar dan kecil.

Adapun faktor-faktor yang mempengaruhi perubahan sosial budaya yakni diantaranya adalah faktor dari dalam dan dari luar masyarakat, faktor dari dalam seperti bertambah dan berkurangnya penduduk, adanya penemuan-penemuan baru, terjadinya konflik, dan adanya pemberontakan atau revolusi. Sedangkan faktor dari luar masyarakat tu sendiri seperti sebab-sebab berasal dari lingkungan, misalnya banjir, gempa bumi, tanah longsor, dll, adanya peperangan dan adanya pengaruh dari budaya asing. 
Kemudian ada keterkaitan antara Antropologi terhadap pembelajaran IPS. Antropologi mengutarakan bagaimana kemampuan individu atau masyarakat dalam menciptakan hasil kebudayaan dengan perkembangannya dari kondisi yang sederhana kepada kondisi yang semakin maju, ialah sumber dan materi yang harus dipelajari dalam pengajaran IPS. Bagaimana daya penyesuaian diri individu ataupun masyarakat diberbagai ruang geografis terhadap kondisi lingkungan setempat yang menghasilkan tingkat kebudayaan yang berbeda-beda adalah materi yang berarti untuk memupuk definisi para siswa kepada kemampuan budaya masyarakat yang berbeda-beda (Hati, 2018: 13),

\section{REFERENSI}

Mutiani, M., Abbas, E. W., Syaharuddin, S., \& Susanto, H. Membangun Komunitas Belajar Melalui Lesson Study Model Transcript Based Learning Analysis (TBLA) dalam Pembelajaran Sejarah.Historia: Jurnal Pendidikdan Peneliti Sejarah, 3(2), 113-122.

Mutiani, M., WARMANSYAH ABBAS, E. R. S. I. S., Syaharuddin, S., \& Susanto, H. (2019). Penerapan Transcript Based Lesson Analyses (TBLA) Sebagai Upaya Peningkatan Pembelajaran Sejarah Di SmaNegeri 7 Banjarmasin.

Susanto, H., Irmawati, I., Akmal, H., \& Abbas, E. W. (2021).Media Film Dokumenter Masuknya Islam Ke Nusantara dan Pengaruhnya Terhadap Keterampilan Berpikir Kritis Siswa. HISTORIA: Jurnal Program Studi Pendidikan Sejarah, 9(1).

Syaharuddin, S., \& Susanto, H. (2019). Sejarah Pendidikan Indonesia (Era PraKolonialisme Nusantara sampai Reformasi).Banjarmasin: FKIP UniversitasLambungMangkurat.

Abbas, E. W. (2013). Mewacanakan Pendidikan IPS. Mewacanakan Pendidikan IPS.

Mutiani, M., Subiyakto, B., Jumriani, J., Aslamiah, A., \& Afrina, A. (2019). Laporan Penelitian: Relevansi Modal Sosial Dalam Pembelajaran IPS (Studi Kasus Dalam Sistem Zonasi Di Smp Negeri Kota Banjarmasin).

Putro, H. P. N., \& Jumriani, J. (2020). Kehidupan Sosial Dan Ekonomi Masyarakat Bantaran Sungai A Sebagai Sumber Belajar Ips.

Indriyani, I. E., Syaharuddin, S., \& Jumriani, J. (2021). Social Interaction Contents on Social Studies Learning to Improve Social Skills. The Innovation of Social Studies Journal, 2(2), 93-102.

Syamsidar, S. (2015). DAMPAK PERUBAHAN SOSIAL BUDAYA TERHADAP PENDIDIKAN. Al-Irsyad Al-Nafs: Jurnal Bimbingan dan Penyuluhan Islam, 2(1). 
Ningrum, E. Konsep Waktu, Perubahan, dan Kebudayaan.

Hati, S. T. (2018). Hubungan Antara Ilmu-ilmu Sosial dan IPS (Sumber dan Materi IPS). IJTIMAIYAH Jurnal Ilmu Sosial dan Budaya, 2(1). 